\title{
First Outbreak of Hong Kong Influenza in a General Practice Population in Great Britain. A Field and Laboratory Study
}

\author{
R. E. HOPE-SIMPSON,* O.B.E., M.R.C.S., L.R.C.P.
}

Suman mmary: The first outbreak of influenza caused by Hong Kong (H.K.) variant of type $A_{2}$ influenza virus in a general practice $(3,620$ persons) in Cirencester, England, lasted 13 weeks, from 15 January to 15 April 1969 , and is estimated to have attacked $4 \%$ of the practice population. The epidemic was too small to produce much effect on the total respiratory morbidity, but when symptom groups were examined separately it could be clearly followed in the class "febrile respiratory disease" in which 76 of the 78 isolations of the virus were made.

Liability to attack was almost independent of age except that persons over 65 were less frequently attacked. In household outbreaks neither schoolchildren nor children under school age were more commonly the first case than their elders. The occurrence of influenza within a household increased the risk of an attack fourfold for the other members, and subsequent cases all occurred within 10 days of the first-consecutive cases within six days of one another.

It is planned to continue surveillance throughout the period of dominance of Hong Kong variants of type $A_{2}$ influenza virus.

\section{Introduction}

The population of a general practice in Cirencester, England, has been under epidemiological observation since 1946 in an attempt to understand certain puzzling features of type $\mathrm{A}$ influenza epidemics.

During the influenza pandemic of 1957, when type $A_{2}$ replaced type $A_{1}$ influenza viruses, a brief but severe outbreak of "Asian" influenza affected some $10 \%$ of the general practice population. Subsequent influenza A epidemics occurred about every two years until 1968, each attacking about $10 \%$ of the general practice population, and seldom causing illness twice in the same person, so that by mid-1968 most persons must have had an attack of type $\mathrm{A}_{2}$ influenza. In all these outbreaks liability to an attack of influenza seemed to be almost independent of age.

In Hong Kong in July 1968 an outbreak of influenza was found to be caused by a type A virus that differed so much from its predecessors (Medical fournal of Australia, 1968) that it seemed likely to displace them. The antigenic change in the virus, however, was not as great as in 1957, and Hong Kong (H.K.) variant has been classified among the type $A_{2}$ influenza viruses (Coleman et al., 1968; Paniker, 1968; Pereira, 1969). Despite the antigenic similarity it has spread all over the world and appears to have replaced previous $A_{2}$ types.

The present paper describes the first visit of H.K. variant to our general practice population.

\section{Methods}

The general practice population, 3,620 persons, is served by two doctors. They took a specimen for virus examination from every patient seen within five days of the onset of any acute respiratory disease. The households of persons with clinical or virologically proved influenza were kept under surveillance by a health visitor, who took a second specimen from the patient and from any other person in the household who developed a respiratory ailment. Acute respiratory illnesses (R.D.) were classified as follows: (1) sore throat, including pharyngitis and tonsillitis; (2) non-febrile R.D., and (3) febrile R.D. Specimens were examined for the presence of influenza virus by the methods already described (Higgins et al., 1964).

\section{Results of General Practice Study}

Some of the numbers in the tables in the general practice study differ from those in the household study because of the presence in some households of persons not on this National Health Service list. There is no evidence of the epidemic in the classes sore throats and non-febrile R.D., but the class febrile R.D. reveals its presence clearly and almost all the isolations of H.K. virus came from disease in this class (Chart and Tables I, II, and III).

The 13 weeks of the practice epidemic are compared with the morbidity in a 13-week non-epidemic period consisting of seven weeks before and six weeks after the epidemic. The epidemic began on 15 January and lasted until 15 April. At the climax, the week ending 25 February, the cases of febrile R.D. numbered nearly four times their non-epidemic weekly average. One minor peak preceded and another succeeded this climax. The epidemic appeared to be dying out in the week ending 22 March, but there was a recrudescence in the first two weeks of April before it ceased. The mimicry of the curve of weekly totals of febrile R.D. by the curve of isolations of H.K. variant (see Chart) again suggests that the febrile R.D. class is giving a true picture of the H.K. influenza epidemic.

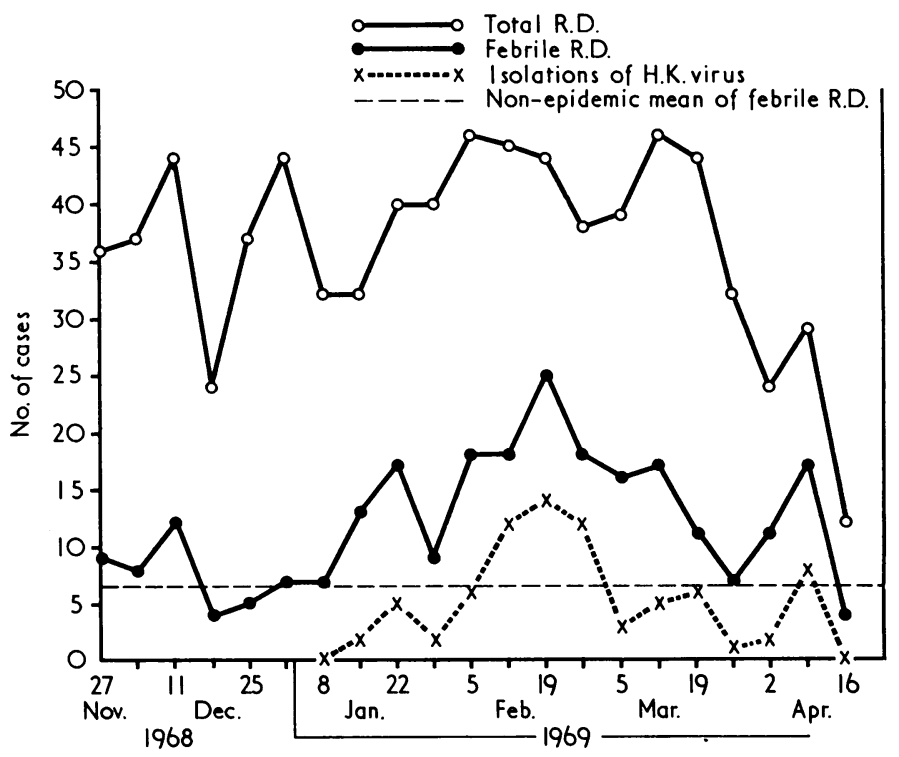

Weekly total of acute respiratory morbidity, febrile R.D., and H.K. influenza virus isolations. 
Table I.-Comparison of 13-week Non-epidemic Period (7 Weeks before and 6 Weeks after Epidemic) with 13-week Epidemic Period. Classified Acute Respiratory Illnesses Seen and Sampled, and Isolations of H.K. Influenza Virus. (Italic type draws attention to presence of epidemic)

\begin{tabular}{|c|c|c|c|c|c|c|c|c|}
\hline & \multicolumn{2}{|c|}{$\begin{array}{l}\text { Non-febrile } \\
\text { R.D. }\end{array}$} & \multicolumn{2}{|c|}{ Febrile R.D. } & \multicolumn{2}{|c|}{$\begin{array}{l}\text { Sore } \\
\text { Throats }\end{array}$} & \multicolumn{2}{|c|}{ Total } \\
\hline & 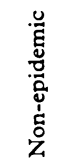 & 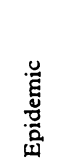 & 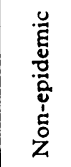 & 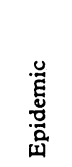 & 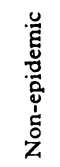 & 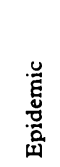 & 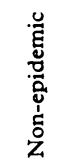 & 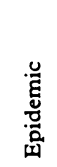 \\
\hline $\begin{array}{l}\text { No. of illnesses } \\
\text { Weekly }\end{array}$ & 210 & 238 & 70 & 197 & 81 & 64 & 361 & 499 \\
\hline $\begin{array}{l}1,000 \text { population) } \quad \ldots \\
\text { Sample of } \\
\text { Percentage of illnesses }\end{array}$ & $\begin{array}{r}4 \cdot 5 \\
51 \\
24 \cdot 3\end{array}$ & $\begin{array}{r}5 \cdot 1 \\
119 \\
50 \cdot 0\end{array}$ & $\begin{array}{r}1.5 \\
41 \\
58.6\end{array}$ & $\begin{array}{c}4 \cdot 2 \\
164 \\
83 \cdot 2\end{array}$ & $\begin{array}{r}1.7 \\
16 \\
19.8\end{array}$ & $\begin{array}{r}1 \cdot 4 \\
38 \\
59 \cdot 4\end{array}$ & $\begin{array}{c}7 \cdot 7 \\
108 \\
29 \cdot 9\end{array}$ & $\begin{array}{l}10 \cdot 6 \\
321 \\
64 \cdot 3\end{array}$ \\
\hline $\begin{array}{l}\text { Isolations of } \mathrm{H} . \mathrm{K} . \\
\text { variant } \\
\text { Percentage of sample }\end{array}$ & $\begin{array}{l}0 \\
0\end{array}$ & $\begin{array}{l}1 \\
0.8\end{array}$ & $(2 \cdot 4)$ & $\begin{array}{r}76 \\
46 \cdot 3\end{array}$ & $\begin{array}{l}0 \\
0\end{array}$ & $2 \cdot 6$ & $\begin{array}{l}(1) * \\
(0 \cdot 9)\end{array}$ & $\begin{array}{l}78 \\
24 \cdot 3\end{array}$ \\
\hline
\end{tabular}

* The one isolation in the non-epidemic period was from a boy brought home with influenza from a distant residential school in which the virus was then epidemic.

TABLE II.-Classified Acute Respiratory Illnesses Seen and Sampled, and Isolations of H.K. Influenza Virus. Non-epidemic Weeks

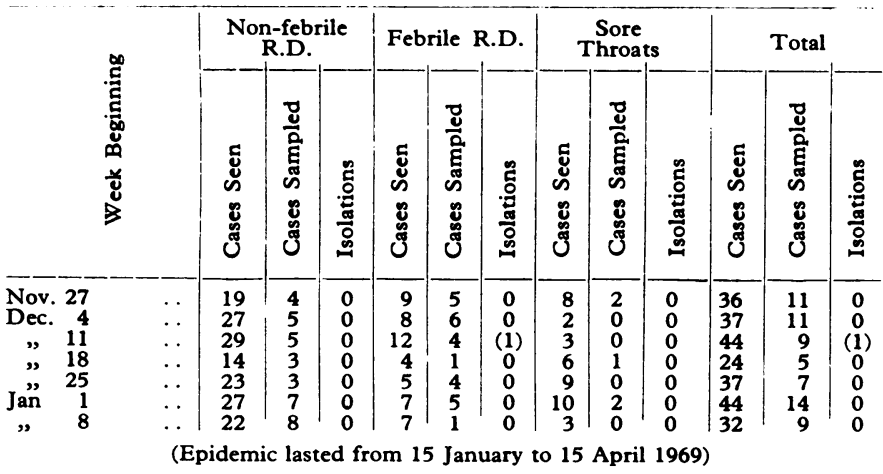

\begin{tabular}{|c|c|c|c|c|c|c|c|c|c|c|c|c|}
\hline $\begin{array}{rr}\text { Apr. } & 16 \\
\text { ” } & 23 \\
\text { May } & 70 \\
\text { ” } 14 \\
\text { ” } & 21 \\
\end{array}$ & $\begin{array}{l}\ldots \\
\cdots \\
\cdots \\
\cdots \\
\cdots\end{array}$ & $\begin{array}{r}9 \\
5 \\
6 \\
7 \\
16 \\
6\end{array}$ & $\begin{array}{l}5 \\
1 \\
2 \\
1 \\
6 \\
1\end{array}$ & $\begin{array}{l}0 \\
0 \\
0 \\
0 \\
0 \\
0\end{array}$ & $\begin{array}{l}4 \\
2 \\
4 \\
4 \\
2 \\
2\end{array}$ & $\begin{array}{l}4 \\
2 \\
4 \\
3 \\
1 \\
1\end{array}$ & $\begin{array}{l}0 \\
0 \\
0 \\
0 \\
0 \\
0\end{array}$ & $\begin{array}{r}0 \\
3 \\
8 \\
8 \\
11 \\
10\end{array}$ & $\begin{array}{l}0 \\
0 \\
0 \\
2 \\
1 \\
5 \\
3\end{array}$ & $\begin{array}{l}0 \\
0 \\
0 \\
0 \\
0 \\
0\end{array}$ & $\begin{array}{l}13 \\
10 \\
18 \\
19 \\
29 \\
18\end{array}$ & $\begin{array}{r}9 \\
3 \\
8 \\
5 \\
12 \\
5\end{array}$ \\
\hline Tota & . & 210 & 51 & 0 & 70 & 41 & (1) & 81 & 16 & 0 & 361 & 108 \\
\hline
\end{tabular}

TABLE III.-Classified Acute Respiratory Illnesses Seen and Sampled, and Isolations of H.K. Influenza Virus. Epidemic Weeks. (Italic type draws attention to effect of epidemic)

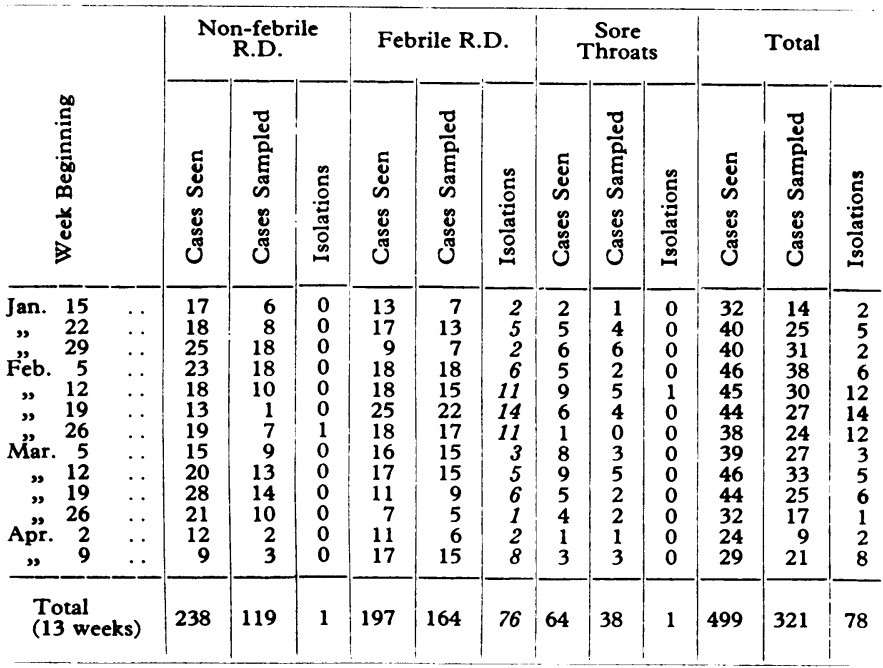

The proportion of specimens which proved positive was highest during the three weeks of the major epidemic wavenamely, $73 \%, 63.5 \%$, and $64 \%$. If allowance is made for an isolation efficiency of not more than $80 \%$, probably 110 persons with influenza consulted the doctors. To obtain an estimate of the total size of the epidemic in the practice population one must allow for missed cases. Table III shows that few minor illnesses were influenzal. Missed cases should therefore be sought among persons with fairly severe illness who did not consult the doctors. By using information from the supplementary household study it is reckoned that not more than 150 persons out of this population of 3,620 had H.K. influenza during this first epidemic in 1969-an incidence of $4 \cdot 1 \%$.

The age incidence is examined in the febrile R.D. class because it has been shown that these cases largely represent the influenza epidemic (Table IV). The epidemic did not increase the morbidity in persons under the age of 10 . Above that age there was a striking increase in morbidity at all ages up to 64 , maximal in the group $45-54$, in which the average weekly number affected was 11 times that in the non-epidemic period (Table IV). Over the age of 65 morbidity was similar to that in the non-epidemic period. Schoolchildren were not selectively attacked (Table V).

The average age of persons with febrile R.D. during the epidemic was 35 years compared with 25 during the non-epidemic period. The epidemic therefore raised the average age of respiratory morbidity in this class of illness. No such change in average age occurred in the other two classes.

TABLE IV.-Classified Acute Respiratory Diseases by Age. (Nonepidemic and Epidemic Average Weekly Morbidity per 1,000 of Popula tion in Age Group. Italic type draws attention to effect of epidemic)

\begin{tabular}{|c|c|c|c|c|c|c|c|c|c|c|}
\hline \multirow[b]{2}{*}{ 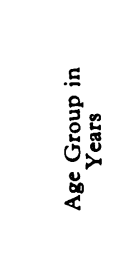 } & & \multirow[b]{2}{*}{ 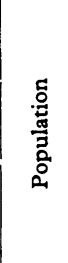 } & \multicolumn{2}{|c|}{$\begin{array}{l}\text { Non-febrile } \\
\text { R.D. }\end{array}$} & \multicolumn{2}{|c|}{ Febrile R.D. } & \multicolumn{2}{|c|}{$\begin{array}{l}\text { Sore } \\
\text { Throats }\end{array}$} & \multicolumn{2}{|c|}{ Total } \\
\hline & & & 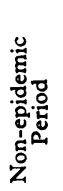 & 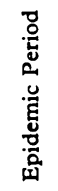 & 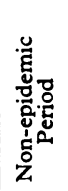 & 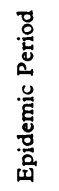 & 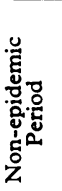 & 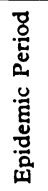 & 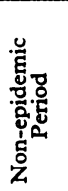 & 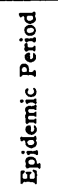 \\
\hline $\begin{array}{c}0-4 \\
5-9 \\
10-14 \\
15-24 \\
25-34 \\
35-44 \\
45-54 \\
55-64 \\
65-74 \\
75-84 \\
85+\ldots\end{array}$ & $\begin{array}{l}. \\
\ldots \\
\ldots \\
\ldots \\
\ldots \\
\ldots \\
\ldots\end{array}$ & $\begin{array}{r}294 \\
247 \\
220 \\
513 \\
397 \\
440 \\
468 \\
477 \\
337 \\
177 \\
50\end{array}$ & $\begin{array}{r}25 \cdot 1 \\
4.5 \\
2 \cdot 3 \\
3.9 \\
5 \cdot 4 \\
4 \cdot 8 \\
2.9 \\
3.7 \\
4 \cdot 8 \\
7.1 \\
10 \cdot 0\end{array}$ & $\begin{array}{r}16 \cdot 1 \\
7 \cdot 4 \\
5 \cdot 2 \\
4 \cdot 6 \\
2 \cdot 5 \\
3 \cdot 5 \\
3 \cdot 9 \\
3 \cdot 8 \\
2 \cdot 3 \\
4 \cdot 8 \\
7 \cdot 7\end{array}$ & $\begin{array}{l}8 \cdot 5 \\
4.5 \\
0.6 \\
1.0 \\
0.9 \\
2 \cdot 0 \\
0.5 \\
1.3 \\
0 \\
2 \cdot 1 \\
5 \cdot 0\end{array}$ & $\begin{array}{l}6 \cdot 3 \\
3.7 \\
4 \cdot 9 \\
3.5 \\
3.5 \\
5 \cdot 2 \\
5 \cdot 6 \\
5 \cdot 0 \\
1 \cdot 4 \\
1.8 \\
1.5\end{array}$ & $\begin{array}{l}3 \cdot 0 \\
4 \cdot 05 \\
1.7 \\
2 \cdot 2 \\
1.9 \\
0 \cdot 8 \\
0.7 \\
1 \cdot 0 \\
0 \\
0.7 \\
0\end{array}$ & $\begin{array}{r}2 \cdot 6 \\
3 \cdot 1 \\
1 \cdot 4 \\
2 \cdot 2 \\
2 \cdot 1 \\
1 \cdot 2 \\
0.5 \\
0 \cdot 5 \\
0 \\
0.5 \\
0\end{array}$ & $\begin{array}{r}36 \cdot 6 \\
13 \cdot 1 \\
4.5 \\
7 \cdot 1 \\
8 \cdot 3 \\
7 \cdot 7 \\
4 \cdot 1 \\
6 \cdot 0 \\
4 \cdot 8 \\
9 \cdot 8 \\
15.0\end{array}$ & $\begin{array}{r}24 \cdot 9 \\
14 \cdot 3 \\
11 \cdot 5 \\
10 \cdot 3 \\
8 \cdot 1 \\
10 \cdot 0 \\
10 \cdot 0 \\
9 \cdot 3 \\
3 \cdot 6 \\
6 \cdot 9 \\
9 \cdot 2\end{array}$ \\
\hline Total & $\ldots$ & 3,620 & 5.9 & $5 \cdot 1$ & $1 \cdot 8$ & $4 \cdot 2$ & $1 \cdot 4$ & $1 \cdot 4$ & $9 \cdot 2$ & $10 \cdot 6$ \\
\hline
\end{tabular}

TABLE V.-Schoolchildren, Pre-school Children, and Adults in Relation to Classified Acute Respiratory Illnesses in Non-epidemic and Epidemic Weeks. (Average Weekly Rate per 1,000 of Population in Age Group. Italic type draws attention to effect of epidemic)

\begin{tabular}{|c|c|c|c|c|c|c|c|c|c|}
\hline \multirow{2}{*}{ 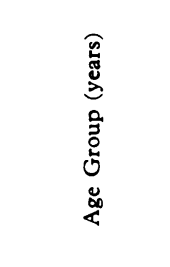 } & \multirow[b]{2}{*}{ 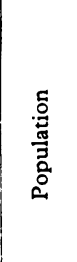 } & \multicolumn{2}{|c|}{$\begin{array}{l}\text { Non-febrile } \\
\text { R.D. }\end{array}$} & \multicolumn{2}{|c|}{ Febrile R.D. } & \multicolumn{2}{|c|}{$\begin{array}{l}\text { Sore } \\
\text { Throats }\end{array}$} & \multicolumn{2}{|c|}{ Total } \\
\hline & & 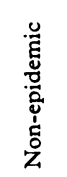 & 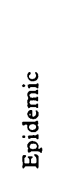 & 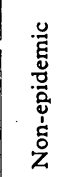 & $\begin{array}{l}\stackrel{.}{\tilde{g}} \\
\text { 苛 }\end{array}$ & 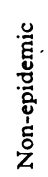 & 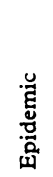 & 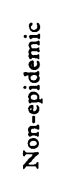 & 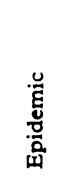 \\
\hline $\begin{array}{c}0-4 \\
15-14(\text { school })\end{array}$ & $\begin{array}{r}294 \\
467 \\
2,859\end{array}$ & $\begin{array}{r}25 \cdot 1 \\
3 \cdot 5 \\
4 \cdot 3\end{array}$ & $\begin{array}{r}16 \cdot 1 \\
6 \cdot 4 \\
3 \cdot 2\end{array}$ & $\begin{array}{l}8 \cdot 5 \\
2 \cdot 7 \\
1 \cdot 1\end{array}$ & $\begin{array}{l}6 \cdot 3 \\
4 \cdot 3 \\
4 \cdot 4\end{array}$ & $\begin{array}{l}3 \cdot 0 \\
2 \cdot 9 \\
1 \cdot 1\end{array}$ & $\begin{array}{l}2 \cdot 6 \\
2 \cdot 3 \\
1 \cdot 1\end{array}$ & $\begin{array}{r}36 \cdot 6 \\
9 \cdot 1 \\
6 \cdot 4\end{array}$ & $\begin{array}{r}24.9 \\
13.0 \\
8.7\end{array}$ \\
\hline Total & 3,620 & 5.9 & $5 \cdot 1$ & $1 \cdot 8$ & $4 \cdot 2$ & $1 \cdot 4$ & $1 \cdot 4$ & $9 \cdot 2$ & $10 \cdot 6$ \\
\hline
\end{tabular}


Once again virus isolations provide evidence that influenza was responsible for these findings. Specimens were obtained from most cases of febrile R.D., and in most age groups H.K. variant was isolated from 40 to $55 \%$ of specimens. The age of persons with febrile R.D. during the epidemic period may therefore be a fair picture of the age incidence of the influenza. The average age of the persons from whom specimens were collected did not differ from that of the whole febrile R.D. class-namely, 35 years. The average age of persons from whom H.K. variant was isolated averaged 37 and that of the whole practice population 38 years. No difference was found in the sex incidence.

Of 112 persons known to have had infection with type $A_{2}$ influenza virus in 1963-8 none was attacked by H.K. variant. Of 70 persons known to have had virus B influenza in 1961-8 one was attacked by H.K. variant. The epidemic was therefore too small to show if any protection was being conferred by a previous type $A_{2}$ influenza virus infection.

\section{Results of Household Study}

There were 1,663 households in the practice, and of these 110 , containing 384 persons, came under surveillance because of a case of clinical or virologically proved influenza. During the epidemic period, 15 January to 15 April, 228 of these persons suffered 272 acute respiratory illnesses of all types, from which 414 specimens were taken for virus study. Seventy-six strains of type $A_{2}$ infuenza virus were isolated, all being the H.K. variant (Table VI).

The breakdown of the 110 households by number of persons in household and number of virus isolations is shown in Table VII. In 49 households there were other persons in contact with a first virus-positive case, and among these the subsequent rate of isolation of the virus from all sorts of acute respiratory illnesses was $17 \%$.

Intervals between cases within households were all 10 days or less, whereas between successive cases they were all less than seven days. The household outbreaks which gave these

TABLE VI.-Age-specific Analysis of Febrile R.D. Class During Epidemic Populations, Illnesses, Samples and Isolations of H.K. Influenza Virus. (Percentages of Population Ill, of Illnesses Sampled, and of Sample Proving Virus-positive are Shown in Parentheses)

\begin{tabular}{|c|c|c|c|c|c|c|c|c|}
\hline \multicolumn{5}{|c|}{ Age } & \multirow{2}{*}{ 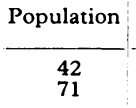 } & \multirow{2}{*}{$\begin{array}{l}\text { Illnesses } \\
4 \\
4\end{array}$} & \multirow{2}{*}{$\begin{array}{l}\text { Sample } \\
\begin{array}{l}3 \\
3\end{array}\end{array}$} & \multirow{2}{*}{$\begin{array}{c}\text { Isolations } \\
1 \\
2\end{array}$} \\
\hline $\begin{array}{r}0-11 \\
12-23\end{array}$ & $\begin{array}{c}\text { months } \\
\#\end{array}$ & $\begin{array}{l}\cdots \\
\cdots\end{array}$ & $\ldots$ & $\begin{array}{l}\cdots \\
\therefore\end{array}$ & & & & \\
\hline $\begin{array}{c}0-4 \\
5-9 \\
10-14 \\
15-24 \\
25-34 \\
35-44 \\
45-54 \\
55-64 \\
65-74 \\
75-84 \\
85+\end{array}$ & $\begin{array}{l}\text { years } \\
\text { ", } \\
\text { ", } \\
\text { ", } \\
\text { ", } \\
\text { " }\end{array}$ & $\begin{array}{l}\ldots \\
\cdots \\
\cdots \\
\cdots \\
\cdots \\
\cdots \\
\cdots \\
\cdots\end{array}$ & $\begin{array}{l}\ldots \\
\ldots \\
\cdots \\
\cdots \\
\cdots \\
\cdots \\
\cdots \\
\cdots\end{array}$ & $\begin{array}{l}. \\
\cdots \\
\cdots \\
\therefore \\
\therefore \\
\therefore \\
\therefore \\
\therefore \\
\therefore\end{array}$ & $\begin{array}{r}294 \\
247 \\
220 \\
513 \\
397 \\
440 \\
468 \\
477 \\
337 \\
177 \\
50 \\
\end{array}$ & $\begin{array}{c}24(8 \cdot 2) \\
12(4 \cdot 9) \\
14(6 \cdot 4) \\
23(4 \cdot 5) \\
18(4 \cdot 5) \\
30(6 \cdot 8) \\
34(7 \cdot 3) \\
31(6 \cdot 5) \\
6(1 \cdot 8) \\
4 \\
1\end{array}$ & $\begin{array}{r}17(70 \cdot 8) \\
9(75 \cdot 0) \\
12(85 \cdot 7) \\
20(87 \cdot 0) \\
15(83 \cdot 3) \\
27(90 \cdot 0) \\
32(94 \cdot 1) \\
25(80 \cdot 6) \\
5(83 \cdot 3) \\
1 \\
1\end{array}$ & $\begin{array}{r}5(29.4) \\
4(44.4) \\
5(41.7) \\
11(55.0) \\
7(46.7) \\
13(48.1) \\
15(46.9) \\
13(52.0) \\
2(40.0) \\
0 \\
1\end{array}$ \\
\hline \multicolumn{2}{|c|}{ Total } & $\ldots$ & . & $\ldots$ & 3,620 & $197(5 \cdot 4)$ & $164(83 \cdot 2)$ & $76(46 \cdot 3)$ \\
\hline
\end{tabular}

TABLE VII.-Isolations of H.K. Influenza Virus in Surveyed Households by Number of Persons in Household

\begin{tabular}{|c|c|c|c|c|c|c|c|c|}
\hline \multirow{2}{*}{\multicolumn{2}{|c|}{$\begin{array}{l}\text { No. of } \\
\text { Persons in } \\
\text { Household }\end{array}$}} & \multicolumn{5}{|c|}{ No. of Isolations } & \multicolumn{2}{|c|}{ Total } \\
\hline & & 0 & 1 & 2 & 3 & 4 & Households & Persons \\
\hline $\begin{aligned} 1 & \ldots \\
2 & \cdots \\
3 & \cdots \\
4 & \cdots \\
5 & \cdots \\
6 & \cdots \\
7 & \cdots \\
8 & \cdots \\
9 & \cdots \\
10 & \cdots\end{aligned}$ & $\begin{array}{l}. \\
\therefore \\
\therefore \\
\therefore \\
\therefore \\
\therefore \\
\therefore\end{array}$ & $\begin{array}{r}5 \\
13 \\
11 \\
15 \\
9 \\
2 \\
1 \\
1 \\
0 \\
0\end{array}$ & $\begin{array}{r}4 \\
8 \\
11 \\
9 \\
3 \\
0 \\
0 \\
0 \\
1 \\
1\end{array}$ & $\begin{array}{l}\overline{2} \\
3 \\
3 \\
2 \\
1 \\
0 \\
0 \\
0 \\
0\end{array}$ & $\begin{array}{l}- \\
\overline{1} \\
1 \\
0 \\
0 \\
1 \\
0 \\
0 \\
0\end{array}$ & $\begin{array}{l}- \\
\overline{-} \\
\overline{0} \\
2 \\
0 \\
0 \\
0 \\
0 \\
0\end{array}$ & $\begin{array}{r}9 \\
23 \\
26 \\
28 \\
16 \\
3 \\
2 \\
1 \\
1 \\
1\end{array}$ & $\begin{array}{r}9 \\
46 \\
78 \\
112 \\
80 \\
18 \\
14 \\
8 \\
9 \\
10\end{array}$ \\
\hline Total & $\ldots$ & 57 & 37 & 11 & 3 & 2 & 110 & 384 \\
\hline
\end{tabular}

intervals are scattered throughout the whole epidemic period of 91 days.

The school status of virus-positive persons, according as they were the first or subsequent cases in their households, is shown in Table VIII.

TABLE VIII.-School-age Child in Relation to Virus Introduction into Household. (Rate per 1,000 of Population in Age Group Shown in Parentheses)

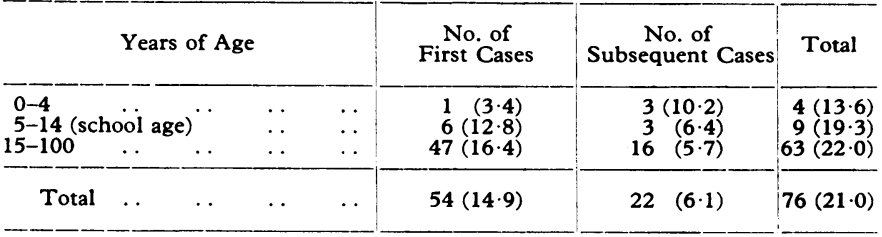

\section{Discussion}

The outbreak was small. Why did it terminate in the presence of $95 \%$ of apparently susceptible subjects? Even where the virus had gained access to the household, $80 \%$ of contacts escaped the disease. Two simple explanations come to mind-namely (1) that many persons had mild or inapparent infections, so that only a small portion of the total outbreak has been recorded, and (2) that H.K. variant did not differ sufficiently from its predecessors to bypass the immunity conferred by them.

Neither explanation is satisfactory. If either were true influenza A would not be expected to recur at such frequent intervals and to continue to attack so many persons of all ages. In the present instance, if most "escapes" have either been subliminally attacked or are immune, no considerable epidemic of H.K. influenza ought to occur in the near future.

Age exerted little effect on the distribution of the influenza epidemic. An epidemic caused by a virus new to a population attacks indiscriminately, so that the age distribution of the disease is similar to that of the population. Subsequently most older groups become immune and the virus comes to depend on recruitment of susceptible subjects by births in the community. Most viruses accordingly find the majority of their victims in the younger age groups. The age distribution of the present influenza epidemic might therefore have been taken as evidence of the antigenic novelty of H.K. variant had it not been for the behaviour of the predecessor viruses. In 1957 the indiscriminate age distribution of Asian influenza was also, and quite reasonably, ascribed to the magnitude of the antigenic change from type $A_{1}$ to type $A_{2}$ virus. Type $A_{2}$ was, in effect, a new virus and everyone was susceptible to it. Epidemics of type $A_{2}$ influenza in 1963, 1964, 1966, and 1968 did not, however, show the expected lowering of the average age of those attacked.

The anomalous age distribution of influenza A may depend on some peculiarity in the mechanism of spread or survival. The low attack rate in persons over 65 agrees with the finding of antibody to H.K. variant, though not to previous type A2 viruses, in the blood of persons born before 1900 (M. F. Warburton, 1969, personal communication).

If an environment is favouring the spread of an infectious agent, infected persons should be more numerous there than in the community at large. If the infections in that environment are also clustered in time when compared with the secular distribution of cases in the general community, the evidence is even stronger: On both these counts the household was favouring the spread of H.K. variant. About $4 \%$ of households and of the practice population were attacked, but within the households the secondary attack rate was $17 \%$. Furthermore, though the household outbreaks were scattered throughout the whole 91 days of the epidemic, the intervals 
between successive cases within a household never exceeded seven days. The household was therefore more favourable than the community to the spread of H.K. variant, the risk to household contacts of the first case being increased fourfold. It is natural to infer that subsequent cases, all of which occurred within 10 days of the first were caused by person-toperson spread. If so, a relatively constant serial interval between successive cases should be present, representing the duration of the human-host parasite reproductive cycle (HopeSimpson, 1948). In this outbreak there are unfortunately too few household case-intervals to provide this decisive evidence.

Many institutional epidemics of H.K. influenza have been recorded in which $30-50 \%$ of inmates were affected. The overall attack rate in our affected households was also about $40 \%$.

The day school in Britain is important in disseminating many viruses, the day scholar being commonly the person to introduce the virus into the household. In this general practice population during the 1951 influenza A epidemic, it appeared (Hope-Simpson, 1951) that whereas day scholars had been the most important group for measles they had played no special part in introducing influenza into the households. The present investigation, examining virus-positive cases, once again found that schoolchildren were no more likely than anyone else to be the first cases in the household, and that children below school age were even less likely (Table VIII).

I would like to thank the following: the Public Health Laboratory Service and the Medical Research Council for providing facilities for the work; Dr. P. G. Higgins and the Cirencester Public Health Virological Laboratory for collaboration; Dr. Marguerite S. Pereira for serological typing of influenza viruses, my partner, Dr. E. J. Guest, and Dr. P. F. Cassidy for helping with recording and taking of specimens; my own staff for endless help and tolerance and my patients for cheerful co-operation; Dr. Allan Withnell and other members of the Gloucestershire County Council Health Department, especially Miss E. Short and Miss D. Little, for cooperation in the household study; and Sir James Howie, Dr. T Pollock, Dr. D. Miller, Dr. G. C. Schild, and Dr. P. G. Higgins for most helpful criticism of this paper.

\section{REFERENCES}

Coleman, M. T., Dowdle, W. R., Pereira, H. G., Schild, G. C., and Chang, W. K. (1968). Lancet, 2, 1384.

Higgins, P. G., Boston, D. G., and Ellis, E. M. (1964). Monthly Bulletin of the Ministry of Health and the Public Health Laboratory tin of the Minice, 23, 93 .

Hope-Simpson, R. E. (1948). Lancet, 2, 755.

Hope-Simpson, R. E. (1951). Proceedings of the Royal Society of Medicine, 44, 798.
.

Medical fournal of Australia, 1968, 2, 962.

Paniker, C. K. J. (1968). Fournal of General Virology, 2, 385.

Pereira, H. G. (1969). Progress in Medical Virology, 11, 46.

\title{
Peritoneal Dialysis for Pulmonary Oedema After Acute Myocardial Infarction
}

\author{
M. P. CHOPRA, ${ }^{*}$ M.B., B.S. ; R. B. GULATI, $\uparrow$ M.D. ; R. W. PORTAL, $\ddagger$ M.D., M.R.C.P. \\ CLIVE P. ABER, $\ddagger$ B.SC., M.D., M.R.C.P.
}

\begin{abstract}
Cummary: Four patients with intractable pulmonary oedema after acute myocardial infarction were treated with peritoneal dialysis. A negative fluid balance was rapidly achieved in three patients, two of whom ultimately survived. The fourth patient, who had complete heart block at the beginning of dialysis, showed initial clinical improvement with restoration of sinus rhythm despite failure to extract fluid.
\end{abstract}

\section{Introduction}

Resolution of chronic intractable congestive heart failure in adults and pulmonary oedema superimposed on refractory heart failure in infants and children has been achieved by the use of peritoneal dialysis (Schneierson, 1949; Bertrand and Guerin, 1961; Nora et al., 1966; Mailloux et al., 1967; Cairns et al., 1968). It therefore seemed reasonable to use this technique to treat pulmonary oedema after acute myocardial infarction when more conventional diuretic measures had failed to produce a satisfactory response. Such patients have a poor prognosis owing to the complications that arise from the associated severe anoxia, hypotension, and metabolic acidosis (Rosenbaum and Levine, 1941; Peel et al., 1962; MacKenzie, 1964; McNicol et al., 1965). This paper describes our initial experience with this method of treating pulmonary oedema after acute myocardial infarction.

\footnotetext{
*Research Assistant.

tSenior House Officer.

$\neq$ Consultant Physician.

Department of Cardiology, Kingston General Hospital, Hull.

SPresent address: Department of Medicine, B. J. Medical College and Sassoon General Hospitals, Poona, India.
}

Peritoneal dialysis was performed on four men with proved acute myocardial infarction. The diagnosis was based on a typical clinical history with characteristic electrocardiographic changes (World Health Organization, 1959) and/or a significant rise in enzymes (aspartate aminotransferase and $\alpha$-hydroxybutyrate dehydrogenase). The clinical details are summarized in Table I.

Blood urea and serum electrolyte studies were carried out before and after dialysis. Serial arterial blood gas and acidbase studies were made on two patients (Table II). Predialysis and post-dialysis portable anteroposterior chest radiographs, taken at a distance of $5 \mathrm{ft}$. $(1.5 \mathrm{~m}$.), were assessed for evidence of cardiac enlargement, pulmonary venous hypertension, pleural effusions, and pulmonary oedema with a modification of the method of Tattersfield et al. (1969). Cardiac size was evaluated from the cardiothoracic ratio-namely, ratio less than $50 \%=0$ mark; $51 \%$ to $60 \%$ $=1$ mark; $61 \%$ or greater $=2$ marks. Pulmonary venous hypertension was assessed by examination of the chest radiographs for (a) upper lobe pulmonary venous congestion (no congestion $=0$ mark; mild congestion $=1$ mark; marked congestion $=2$ marks), and (b) evidence of septal lines (no septal lines $=0$ mark; septal lines $=1$ mark). A pleural effusion, if present, scored 1 mark. Pulmonary oedema was evaluated on the basis of its presence ( 1 mark) or absence ( 0 mark) in the upper, middle, and lower zones (assessed separately) of each lung field. This gave a possible maximum total of 6 marks and, though arbitrary, enabled us to record changes in the degree of oedema. Accurate measurement of the width of the superior mediastinum proved impossible; Tattersfield et al. (1969) also found this measurement unreliable. 